\title{
Sedap institucionalizará o planejamento administrativo
}

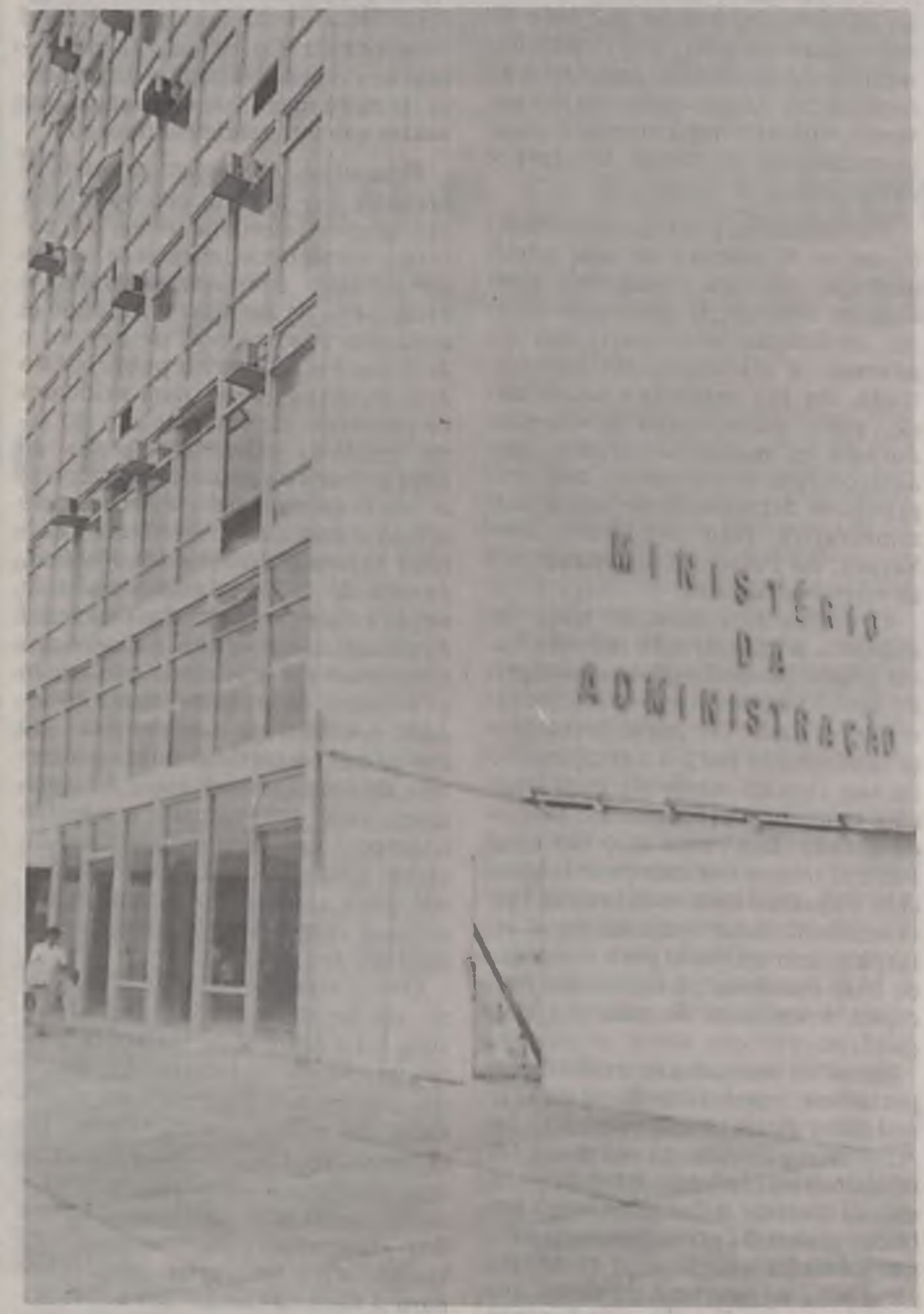

O edificio-sede da nova Secretaria terá de mudar de nome

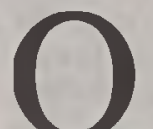

decreto fundamental da Reforma Administrativa é o que agiliza a autoridade funcional sobre politica de pessoal, modernização e desburocratização administrativas, serviços gerais do Governo Federal, formação de quadros e treinamento de servidores. Trata-se da Secretaria de Administração Pública da Presidência da República (Sedap), criada por decreto presidencial, a 3 de setembro último, no despacho coletivo do presidente Sarney com os ministros Aluizio Alves, Dílson Funaro, João Sayad, Marco Maciel e Almir Pazzianolto.

A Sedap substituirá o antigo Ministerrio Extraordinário da Administração, que, ainda sem sua instituição oficializada, assentava-se na estrutura do antigo Dasp.

Agora, com um âmbito de atuação mais ampliado, e contando com a força institucional de órgão da Presidência da República, a Sedap estará apta para atuar com maior flexibilidade e apoio, para a execucão das politicas de reestruturação organizacional do Governo Federal, que não serão de curto, nem de médio prazos, dado que constituem um processo continuo.

O Ministro Aluizio Alves, a propósito da criação da Sedap, enviou mensagem a todos os servidores públicos do País, através do JORNAL DA REFORMA ADMINISTRATI$V A$, que circulou 24 horas após a assinatura dos decretos presidenciais.

"Estamos iniciando hoje a execução da Reforma Administrativa, dando vida ao compromisso do Presidente José Sarney de modernizar a administração publica brasileira, preparando-a para o Século XXI.

Foi utn trabalho incansável de to- 
do o Cioverno, para fazer face à situação caótica que tornou o servico público um amontoado de complexidades e perplexidades, ao longo das últimas decadas.

Por isso é que a Reforma Administrativa não tem prazos: ela comeća agora, mas seguirá com outros esforços para desobstruir a máquina administrativa, emperrada e desmolivada.

Essa e uma reforma histórica, que consagrará o governo José Sarney, não tenho dúvida nenhuma. Pois seu objetivo é valorizar a carreira do servidor publico, democratizar as oportunidades de acesso à adminisIração pública direta e indireta, e agilizar o desempenho do Governo Federal.

Como Secretaria de Administracão da Presidência da República, teremos mais flexibilidades e recursos instrumentais para seguir adiante com a Reforma hoje iniciada. Nosso compromisso é com a qualidade do serviço público prestado ao cidadão, fazendo de cada servidor brasileiro um profissional dignificado $\mathrm{e}$ reconhecido em sua carreira".

\section{O ORGANOGRAMA DA SEDAP}

A Sedap passa a ter, em seu organograma, algumas figuras novas, como o Conselho Interministerial de Remuneração e Proventos (CIRP). que será presidido pelo titular da Secretaria.

Imediatamente após sua criação, foi extinto o antigo Departamento Administrativo do Serviço Público (Dasp), cujos bens, recursos orcamentários e financeiros, e competência, passaram à nova Secretaria.

$\mathrm{Na}$ Sedap, ficaram incluidos o Programa Nacional de Desburocratização, a Secretaria de Modernização e Reforma Administrativa (Semor), e a Superintendênçia de Construção e Administração Imobiliária (Sucad).

Como instituição vinculada, permaneceu a Fundaçáo - Centro de Formação do Servidor Público (Funcep).

Foi instituido o Sistema de Modernização Administrativa da Administração Federal e autárquica. E a Sedap passou também a exercer as funçỏes de órgão central dos sistemas de Pessoal Civil, Serviços Gerais e de Modernização Administrativa, por intermédio de unidades de sua estrutura básica.

A estrutura básica da Sedap se comporá (1) dos órgãos de assistência direta e imediata do Ministro de Estado: Gabinete do Ministro; Consultoria Juridica; Assessoria de Segurança e Informaçōes; Assessoria de Comunicação Social e Assessoria de Assuntos Parlamentares; (2) órgãos superiores de planejamento, coordenação e controle financeiro: Secretaria-Geral e Secretaria de Controle Interno; (3) órgãos centrais de sistemas: Secretaria de Recursos Humanos; Secretaria de Modernização Administrativa; Secretaria de Serviços Gerais; (4) órgāos de direção superior: Departamento de Administração e Departamento de Pessoal; (5) órgão autônomo: Superintendência de Construção e Administraçāo Imobiliária (Sucad); e (6) entidade vinculada: FundaçãoCentro de Formação do Servidor Público (Funcep).

Instilucionalizaça do Planejamento - Um aspecto fun- damental a ser observado com a criação da Sedap é que, na presidência da República, a Seplan já vinha exercendo a função de órgão de planejamento econômico, e o Gabinete Civil, de planejamento e coordenacão geral do governo. A Sedap, agora, passa a ser instrumento de planejamento administrativo no mais alto nivel, e na abrangência politica de que só a Presidência da República dispõe.

Essa institucionalização do planejamento administrativo, fundamenlal para a adequação da máquina do Governo às suas reformas e programas, permitirá o prestigiamento da função pública em seu mais elevado aspecto, pois haverá prioridade para a Reforma Administrativa, em seus desmembramentos futuros, no sentido de prestigiar o servidor, valorizar a carreira pública e renovar os quadros da administração através da formação e do treinamento. 